\title{
Assessment of Full-Scale N2O Emission Characteristics and Testing of Control Concepts in an Activated Sludge Wastewater Treatment Plant with Alternating Aerobic and Anoxic Phases
}

Chen, Xueming; Mielczarek, Artur Tomasz; Habicht, Kirsten; Andersen, Mikkel Holmen; Thornberg, Dines; Sin, Gurkan

Published in:

Environmental Science \& Technology

Link to article, DOI:

10.1021/acs.est.9b04889

Publication date:

2019

Document Version

Peer reviewed version

Link back to DTU Orbit

Citation (APA):

Chen, X., Mielczarek, A. T., Habicht, K., Andersen, M. H., Thornberg, D., \& Sin, G. (2019). Assessment of FullScale N O Emission Characteristics and Testing of Control Concepts in an Activated Sludge Wastewater Treatment Plant with Alternating Aerobic and Anoxic Phases. Environmental Science \& Technology, 53(21), 12485-12494. https://doi.org/10.1021/acs.est.9b04889

\section{General rights}

Copyright and moral rights for the publications made accessible in the public portal are retained by the authors and/or other copyright owners and it is a condition of accessing publications that users recognise and abide by the legal requirements associated with these rights.

- Users may download and print one copy of any publication from the public portal for the purpose of private study or research.

- You may not further distribute the material or use it for any profit-making activity or commercial gain

- You may freely distribute the URL identifying the publication in the public portal 


\section{Assessment of Full-Scale NO Emission Characteristics and Testing of Control Concepts in an Activated Sludge Wastewater Treatment Plant with Alternating Aerobic and Anoxic Phases}

Xueming Chen, Artur Tomasz Mielczarek, Kirsten Habicht, Mikkel Holmen Andersen, Dines Thornberg, and Gurkan Sin

Environ. Sci. Technol., Just Accepted Manuscript • DOI: 10.1021/acs.est.9b04889 • Publication Date (Web): 08 Oct 2019

Downloaded from pubs.acs.org on October 10, 2019

\section{Just Accepted}

"Just Accepted" manuscripts have been peer-reviewed and accepted for publication. They are posted online prior to technical editing, formatting for publication and author proofing. The American Chemical Society provides "Just Accepted" as a service to the research community to expedite the dissemination of scientific material as soon as possible after acceptance. "Just Accepted" manuscripts appear in full in PDF format accompanied by an HTML abstract. "Just Accepted" manuscripts have been fully peer reviewed, but should not be considered the official version of record. They are citable by the Digital Object Identifier (DOI®). "Just Accepted" is an optional service offered to authors. Therefore, the "Just Accepted" Web site may not include all articles that will be published in the journal. After a manuscript is technically edited and formatted, it will be removed from the "Just Accepted" Web site and published as an ASAP article. Note that technical editing may introduce minor changes to the manuscript text and/or graphics which could affect content, and all legal disclaimers and ethical guidelines that apply to the journal pertain. ACS cannot be held responsible for errors or consequences arising from the use of information contained in these "Just Accepted" manuscripts. 
1 Assessment of Full-Scale $\mathrm{N}_{2} \mathrm{O}$ Emission Characteristics and Testing of Control Concepts

2 in an Activated Sludge Wastewater Treatment Plant with Alternating Aerobic and

$3 \quad$ Anoxic Phases

4

5 Xueming Chen ${ }^{1, *}$, Artur Tomasz Mielczarek ${ }^{2}$, Kirsten Habicht $^{3}$, Mikkel Holmen Andersen ${ }^{3}$,

6 Dines Thornberg ${ }^{2}$, Gürkan $\operatorname{Sin}^{1, *}$

7

${ }^{1}$ Process and Systems Engineering Center (PROSYS), Department of Chemical and

9 Biochemical Engineering, Technical University of Denmark, 2800 Kgs. Lyngby, Denmark.

${ }^{2}$ Biofos A/S, Refshalevej 250, 1432 Copenhagen, Denmark.

${ }^{3}$ Unisense Environment A/S, Tueager 1, DK-8200 Aarhus N, Denmark.

*Corresponding authors:

Dr. Xueming Chen, Phone: +45 8194 8080, E-mail: xuem.chen@hotmail.com

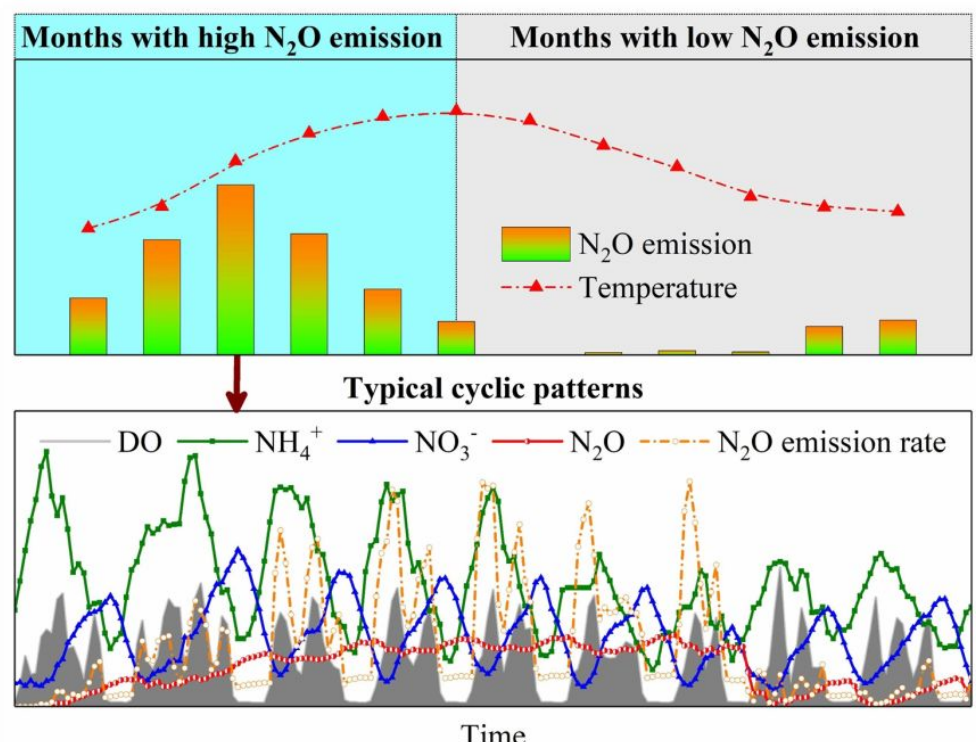




\section{ABSTRACT}

20

21

This work aims to obtain full-scale $\mathrm{N}_{2} \mathrm{O}$ emission characteristics translatable into viable $\mathrm{N}_{2} \mathrm{O}$ control strategies and conduct full-scale testing of the proposed $\mathrm{N}_{2} \mathrm{O}$ control concepts. Data of a long-term monitoring campaign was firstly used to quantify full-scale $\mathrm{N}_{2} \mathrm{O}$ emission and probe into the seasonal pattern. Then trends between $\mathrm{N}_{2} \mathrm{O}$ production/emission and process variables/conditions during typical operating cycles were revealed to explore the dynamic $\mathrm{N}_{2} \mathrm{O}$ emission behavior. A multivariate statistical analysis was performed to find the dependency of $\mathrm{N}_{2} \mathrm{O}$ emission on relevant process variables. The results show for the first time that relatively low/high $\mathrm{N}_{2} \mathrm{O}$ emission took place in seasons with a decreasing/increasing trend of water temperature, respectively. Aerobic phase contributed to $\mathrm{N}_{2} \mathrm{O}$ production/emission probably mainly through the hydroxylamine pathway. Comparatively, heterotrophic bacteria had a dual role in the anoxic phase and could be responsible for both net $\mathrm{N}_{2} \mathrm{O}$ production and consumption. Incomplete denitrification might contribute mainly to the $\mathrm{N}_{2} \mathrm{O}$ production/emission in the anoxic phase and the accumulation of $\mathrm{N}_{2} \mathrm{O}$ to be significantly emitted in the following cycle due to the competition between different denitrification steps for electron donors. Therefore, properly extending the length of anoxic phase could serve as a potential control means to regulate $\mathrm{N}_{2} \mathrm{O}$ accumulation in the anoxic phase. The full-scale testing not only verified the efficacy of reduced dissolved oxygen set-point in reducing $\mathrm{N}_{2} \mathrm{O}$ emission by $60 \%$, but also confirmed the proposed concepts of control over the aerobic and anoxic phases collectively. 


\section{INTRODUCTION}

Wastewater treatment plants (WWTPs) have been regarded as an important contributor to the global greenhouse gas stock through the production and emission of nitrous oxide $\left(\mathrm{N}_{2} \mathrm{O}\right)^{1,2}$, which has a global warming effect 265 times stronger than carbon dioxide on a 100 -year time horizon ${ }^{3}$. Moreover, $\mathrm{N}_{2} \mathrm{O}$ is a scavenger of ozone and therefore plays an important role in the destruction of the stratospheric ozone layer ${ }^{4}$. Therefore, on one hand, $\mathrm{N}_{2} \mathrm{O}$ emission should be accurately quantified to assess the performance of WWTPs comprehensively. On the other hand, timely measures should be taken to mitigate full-scale $\mathrm{N}_{2} \mathrm{O}$ emission.

Despite the fixed, low level of $0.035 \%$ suggested by IPCC ${ }^{3}$, a significantly varied $\mathrm{N}_{2} \mathrm{O}$ emission factor has been reported for full-scale WWTPs, ranging from 0 to $14.6 \%$ relative to incoming nitrogen ${ }^{2,5-8}$. This variability is due to the existence of multiple $\mathrm{N}_{2} \mathrm{O}$ production contributing pathways (i.e., the nitrifier denitrification pathway and the hydroxylamine pathway mediated by ammonium-oxidizing bacteria (AOB) during nitrification ${ }^{9}$ and the sequential heterotrophic denitrification which is carried out by heterotrophic bacteria (HB) and involves $\mathrm{N}_{2} \mathrm{O}$ as an obligate intermediate ${ }^{1}$ ), which are regulated by a number of affecting process variables (e.g., dissolved oxygen (DO), carbon source, $\mathrm{NO}_{2}^{-}, \mathrm{pH}$, and temperature ${ }^{10}$ ).

Long-term measurement campaigns are therefore needed to clearly demonstrate full-scale $\mathrm{N}_{2} \mathrm{O}$ emission characteristics under various process conditions. Analyses of long-term data to reliably deduce the relationships between $\mathrm{N}_{2} \mathrm{O}$ emission and relevant process variables ${ }^{11}$ serve as the basis of developing viable $\mathrm{N}_{2} \mathrm{O}$ control strategies. Although long-term measurement campaigns and relevant analyses have been reported ${ }^{12}$, the insights obtained are largely dependent on the plant/process design applied and the control strategy involved and cannot be generalized to all types of WWTPs. With respect to $\mathrm{N}_{2} \mathrm{O}$ control strategies, only limited work 
based on model simulations has been reported ${ }^{13}$. The numerous $\mathrm{N}_{2} \mathrm{O}$ models available are seldom calibrated or verified using highly dynamic full-scale data in the long term ${ }^{11}$, thus bringing high uncertainty to the validity of the model-based $\mathrm{N}_{2} \mathrm{O}$ control strategies. In this case, data-driven development of $\mathrm{N}_{2} \mathrm{O}$ control strategies, which is rarely performed, serves as a reliable alternative. Despite all the reported efforts, to the best of our knowledge, no full-scale testing has been conducted to verify the efficacy of the $\mathrm{N}_{2} \mathrm{O}$ control strategies proposed based on the analyses of long-term measurements of $\mathrm{N}_{2} \mathrm{O}$ as well as other relevant process variables.

In view of the aforementioned, this work aims to obtain full-scale $\mathrm{N}_{2} \mathrm{O}$ emission characteristics that could be translated into viable $\mathrm{N}_{2} \mathrm{O}$ control strategies and conduct full-scale testing of the proposed $\mathrm{N}_{2} \mathrm{O}$ control concepts. To this end, data of a long-term monitoring campaign at a large Danish WWTP was firstly used to quantify full-scale $\mathrm{N}_{2} \mathrm{O}$ emission and probe into seasonal pattern. Then trends between $\mathrm{N}_{2} \mathrm{O}$ production/emission and process variables during typical operating cycles were revealed to probe into the dynamic $\mathrm{N}_{2} \mathrm{O}$ emission behavior. A multivariate statistical analysis was performed to find the dependency of $\mathrm{N}_{2} \mathrm{O}$ emission on relevant process variables. Based on the analysis results, potentially viable $\mathrm{N}_{2} \mathrm{O}$ control strategies were proposed and then tested directly at the studied WWTP. Given the technical constraints on site and the crucial role of the studied WWTP in the public sector, not all process variables of interest were measured or could be made available. Therefore, the analyses conducted in this work followed the rule of making the most of the data readily available to obtain insightful but practical information. Overall, this work goes beyond the current state of the art by integrating full-scale data analyses with control concept testing in order to mitigate $\mathrm{N}_{2} \mathrm{O}$ production/emission from WWTPs.

\section{MATERIALS AND METHODS}




\subsection{Plant/Process Description and Data Origin}

This work was based on the on-line data recorded at Avedøre WWTP (Copenhagen, Denmark), with a capacity of serving approximately $350,000 \mathrm{PE}$ by treating around $70,000 \mathrm{~m}^{3}$ of wastewater daily under dry weather conditions. Combined with screening, grit removal, primary settlement, and secondary clarification in the mainstream treatment, activated sludge process is applied in four Carrousel reactors working in parallel, each consisting of two compartments alternatively fed and intermittently aerated as aerobic (aerated) or anoxic (nonaerated) zones (Fig. 1). Aeration is achieved with bubble diffusers mounted at the bottom of compartments and is activated when DO concentration is lower than the DO set-point which is determined based on in-situ $\mathrm{NH}_{4}{ }^{+}$concentration and is pre-set in the STAR Control ${ }^{\circledR}$ implemented (see Fig. S1A in the Supplementary Materials). The STAR Control ${ }^{\circledR}$ also regulates the entering/exiting of aerobic/anoxic phase of each compartment through the pre-set relationship between in-situ $\mathrm{NH}_{4}{ }^{+}$and $\mathrm{NO}_{3}{ }^{-}$concentrations (see Fig. S1B in the Supplementary Materials), thus ensuring good nitrogen removal performance. As a result, the average effluent quality reached $4.40 \mathrm{~g} \mathrm{~m}^{-3}$ for total nitrogen (TN) in 2017. For the side-stream treatment, anaerobic digestion is applied to produce biogas from primary and secondary sludge, which is then harvested for electricity generation.

$\mathrm{NH}_{4}{ }^{+}-\mathrm{N}, \mathrm{NO}_{3}^{-}-\mathrm{N}, \mathrm{DO}$, and water temperature are constantly monitored in both compartments of all four reactors, while liquid-phase $\mathrm{N}_{2} \mathrm{O}$ is additionally measured using Unisense ${ }^{\circledR} \mathrm{N}_{2} \mathrm{O}$ sensors in two reactors (i.e., Reactor 1 and Reactor 3). As indicated in Fig. 1, the measuring sensors are placed in the same location with respect to the water flow direction in each compartment. All sensors are frequently calibrated and tested, thus ensuring the accuracy of measurements. Instead of the direct measurement of airflow rate into each compartment, the opening of aeration valve in each compartment and the total airflow into all reactors are 
113

114

115

116

117

monitored. Influent flowrate into each reactor is also recorded online using a flow meter. Composite samples over $24 \mathrm{~h}$ are analyzed every one or two weeks to indicate influent quality.

\subsection{Data Processing}

The 12-month monitoring period spanned from March 2018 to February 2019. Similar to Vasilaki et al. ${ }^{11}$, the data, after being extracted from the supervisory control and data acquisition (SCADA) system, was firstly processed to ensure its quality through i) data synchronization under the same time-stamp and ii) removal of unreliable measurements (e.g., significantly negative readings due to sensor drifting, readings outside the sensor measurement range, and readings taken when sensors were not in service). The on-line data for all process variables investigated in this work was aggregated into averages every 5 minutes for subsequent analyses and interpretations and is provided in the Supplementary Data.

\subsection{Data Analyses}

\subsection{1. $\mathrm{N}_{2} \mathrm{O}$ emission rate calculation}

To calculate $\mathrm{N}_{2} \mathrm{O}$ emission rate, equations were differentiated for aerobic (aerated) and anoxic (non-aerated) zones as follows ${ }^{14,15}$ :

Aerobic (aerated) zone: $r_{N 2 O}=H_{N 2 O} \times S_{N 2 O} \times\left[1-e^{-\frac{K_{L} a_{N 2 O}^{\text {Aerated }}}{H_{N 2 O}} \frac{V_{R}}{Q_{A}}}\right] \times \frac{Q_{A}}{V_{R}}$

Anoxic (non-aerated) zone: $r_{N 2 O}=K_{L} a_{N 2 O}^{\text {Non-aerated }} \times\left[S_{N 2 O}-\frac{C_{N 2 O, a i r}}{H_{N 2 O}}\right]$

$r_{N 2 O}$ : Volumetric $\mathrm{N}_{2} \mathrm{O}$ emission rate $\left(\mathrm{g}-\mathrm{N} \mathrm{m}^{-3} \mathrm{~d}^{-1}\right), H_{N 2 O}$ : Dimensionless Henry's constant, $S_{N 2 O}$ : liquid-phase $\mathrm{N}_{2} \mathrm{O}$ concentration $\left(\mathrm{g}-\mathrm{N} \mathrm{m}{ }^{-3}\right), K_{L} a_{N 2 O}^{\text {Aerated }}$ : Aerated $\mathrm{N}_{2} \mathrm{O}$ mass transfer coefficient $\left(\mathrm{d}^{-1}\right), V_{R}$ : Volume of aerated part $\left(\mathrm{m}^{3}\right), Q_{A}$ : Airflow rate $\left(\mathrm{m}^{3} \mathrm{~d}^{-1}\right), K_{L} a_{N 2 O}^{\text {Non-aerated }}$ : 
135 Non-aerated $\mathrm{N}_{2} \mathrm{O}$ mass transfer coefficient $\left(\mathrm{d}^{-1}\right), C_{N 2 O \text {,air }}: \mathrm{N}_{2} \mathrm{O}$ concentration in air equilibrium $136 \quad\left(\mathrm{~g}-\mathrm{N} \mathrm{m}^{-3}\right)$.

137

$K_{L} a_{N 2 O}^{\text {Aerated }}$ was determined according to Eq. $3^{15}$ while $K_{L} a_{N 2 O}^{\text {Non-aerated }}$ was calculated following Eq. $4{ }^{16}$. $Q_{A}$ into each compartment was calculated by proportioning the total airflow measurement based on the ratio of the valve opening measurement in the compartment to the sum of all valve opening measurements.

$$
K_{L} a_{N 2 O}^{\text {Aerated }}=\left[\frac{D_{R}}{0.815}\right]^{-0.49} \times 34500 \times\left[\frac{Q_{A}}{S_{A}}\right]^{0.86} \times 1.024^{(T-20)}
$$

$D_{R}$ : Depth over diffusers $(\mathrm{m}), S_{A}$ : Size of aeration field $\left(\mathrm{m}^{2}\right), \mathrm{T}$ : Temperature $\left({ }^{\circ} \mathrm{C}\right)$.

\subsubsection{Pearson's partial correlation analysis}

A clear understanding of the impacts of process variables on $\mathrm{N}_{2} \mathrm{O}$ emission is the key to the reliable formulation of $\mathrm{N}_{2} \mathrm{O}$ control strategies. To this end, Pearson's partial correlation which measures the degree of association between two variables with the effect of other affecting variables removed was used in this work. More details about Pearson's partial correlation analysis are provided in the Supplementary Materials. Using $\mathrm{N}_{2} \mathrm{O}$ emission rate as the outcome variable and relevant process variables $\left(\mathrm{NH}_{4}{ }^{+}-\mathrm{N}, \mathrm{NO}_{3}{ }^{-}-\mathrm{N}, \mathrm{DO}\right.$, water temperature, influent, etc.) as the affecting variables, Pearson's partial correlation analysis, which accounted for the contributions of other affecting variables while indicating the individual contribution of the process variable studied to $\mathrm{N}_{2} \mathrm{O}$ emission, returned a coefficient (PCC) in the range from -1 to 
no linear relationship. Pearson's partial correlation analysis was conducted using a MATLAB function in Statistics and Machine Learning Toolbox called partialcorri, which also returned a p-value for testing the hypothesis of no partial correlation against the alternative that there was a non-zero partial correlation. Despite the criticisms about using the p-value ${ }^{17}$ mainly in the cases with relatively small data samples, similar criticisms haven't been found in the context of engineering analysis that typically features a large volume of data. Therefore, the p-value, which has been widely applied to assess statistical significance in similar works ${ }^{8,}{ }^{11}$, was directly adopted in this work. If the p-value was less than 0.05 , then the partial correlation was regarded as significantly different from zero. It should be acknowledged that other significance tests not relying on the p-value such as the surrogate model based sensitivity analysis ${ }^{18}$ can also be used in the future for comparative analysis.

\section{RESULTS AND DISCUSSION}

\subsection{Seasonal $\mathrm{N}_{2} \mathrm{O}$ Emission Pattern}

172 As depicted in Fig. 2A, a distinct relationship between monthly average of $\mathrm{N}_{2} \mathrm{O}$ emission rate and water temperature has been observed for Reactor 3 over the monitoring period. The average $\mathrm{N}_{2} \mathrm{O}$ emission rate was $0.77 \mathrm{~g}-\mathrm{N} \mathrm{m}^{-3} \mathrm{~d}^{-1}$ at the average water temperature of $10.7^{\circ} \mathrm{C}$ in March 2018 when the monitoring campaign commenced. With the increasing water temperature, the $\mathrm{N}_{2} \mathrm{O}$ emission rate increased, reaching its peak monthly average of $2.30 \mathrm{~g}-\mathrm{N} \mathrm{m}^{-3} \mathrm{~d}^{-1}$ at the average water temperature of $16.4{ }^{\circ} \mathrm{C}$ in May 2018. Further increase in the water temperature brought down the $\mathrm{N}_{2} \mathrm{O}$ emission rate, arriving at $0.45 \mathrm{~g}-\mathrm{N} \mathrm{m}^{-3} \mathrm{~d}^{-1}$ at the average water temperature of $20.6^{\circ} \mathrm{C}$ in August 2018. Afterwards, the water temperature entered a decreasing stage. In September 2018 when the average water temperature was $19.8^{\circ} \mathrm{C}$, the minimum monthly average of $\mathrm{N}_{2} \mathrm{O}$ emission rate was achieved at $0.01 \mathrm{~g}-\mathrm{N} \mathrm{m}^{-3} \mathrm{~d}^{-1}$. Continuous decrease in the water temperature towards $12.1{ }^{\circ} \mathrm{C}$ in February 2019 (i.e., the end of the monitoring 
campaign) led to the gradual recovery of the $\mathrm{N}_{2} \mathrm{O}$ emission rate. With a high Pearson's correlation coefficient of $0.93(\mathrm{p}=0.00)$, the analogous results for Reactor 1 in Fig. $2 \mathrm{~B}$ prove the reproducibility of the seasonal pattern of $\mathrm{N}_{2} \mathrm{O}$ emission observed for Reactor 3 (i.e., Fig. 2A). In fact, this seasonal pattern of $\mathrm{N}_{2} \mathrm{O}$ emission with respect to water temperature in the range between $10{ }^{\circ} \mathrm{C}$ and $20^{\circ} \mathrm{C}$ is similar to the one observed for a Dutch WWTP which had a different plant/process design and was subject to a diverse control scheme ${ }^{8}$. However, Kosonen et al. ${ }^{19}$ reported a distinct, less pronounced seasonal pattern of $\mathrm{N}_{2} \mathrm{O}$ emission in relation to water temperature for a Finnish WWTP which was also configured and controlled differently compared to the WWTP investigated in this work.

Given that the direct impact of water temperature might be coupled with those of process design and operation, only the overall impact of water temperature on $\mathrm{N}_{2} \mathrm{O}$ emission was studied in this work. On the whole, the monitoring period could be divided into two sub-periods: subperiod with relatively high $\mathrm{N}_{2} \mathrm{O}$ emission and sub-period with relatively low $\mathrm{N}_{2} \mathrm{O}$ emission. As indicated in Fig. 2, the sub-period with relatively high $\mathrm{N}_{2} \mathrm{O}$ emission was characterized by an increasing trend of water temperature (i.e., between March 2018 and August 2018), while the sub-period with relatively low $\mathrm{N}_{2} \mathrm{O}$ emission was featured with a decreasing trend of water temperature (i.e., from August 2018 to February 2019). Despite the real-time $\mathrm{N}_{2} \mathrm{O}$ emission dynamics, the general correlation between the seasonal $\mathrm{N}_{2} \mathrm{O}$ emission and the changing trend of water temperature should be largely attributed to the various responses of functional microorganisms involved in nitrogen conversion reactions (including $\mathrm{AOB}$, nitrite-oxidizing bacteria (NOB), and $\mathrm{HB}$ ) to changes in temperature. Although biological activities are known to accelerate with increasing temperature within a suitable temperature range, each type of functional microorganisms has its own specific temperature dependency. This could be one of the reasons the maximum and minimum $\mathrm{N}_{2} \mathrm{O}$ emission rates didn't correlate directly with the 
extremum water temperature conditions (see Fig. 2A). This proposed hypothesis regarding microbial responses to temperature changes in this work warrants future investigations. A higher-resolution snapshot of the dynamic profiles of process variables in the two parallel reactors (Fig. S2 in the Supplementary Materials) shows the existence of periods with similar concentrations and behavior of $\mathrm{NH}_{4}{ }^{+}, \mathrm{NO}_{3}{ }^{-}$, and $\mathrm{DO}$ but different ranges and responses of $\mathrm{N}_{2} \mathrm{O}$ in the two parallel reactors. On the whole, the notably different magnitude of $\mathrm{N}_{2} \mathrm{O}$ emission rates between the two parallel reactors operated under the same conditions in Figs. 2A and 2B, especially in the sub-period with relatively high $\mathrm{N}_{2} \mathrm{O}$ emission, might also be the result of the different amount of biomass as well as the diverse local microbial community structures shaped after long-term operation. For example, in June 2018 when $\mathrm{N}_{2} \mathrm{O}$ emission was relatively high, the mixed liquor suspended solids (MLSS) concentration in Reactor 1 was $2.02 \pm 0.58 \mathrm{~kg} \mathrm{~m}^{-3}$ while it was $2.60 \pm 0.52 \mathrm{~kg} \mathrm{~m}^{-3}$ in Reactor 3. Therefore, monitoring on one reactor might not reflect the $\mathrm{N}_{2} \mathrm{O}$ emission from other parallel reactors. In other words, reliable quantification of the plant-wide $\mathrm{N}_{2} \mathrm{O}$ emission might necessitate respective monitoring on all different reactors. There is no doubt that this argument would be further verified upon the future availability of additional $\mathrm{N}_{2} \mathrm{O}$ emission results of the other two parallel reactors. Although there were also two parallel Carrousel reactors being monitored in the study of Daelman et al. ${ }^{8}$, the respective $\mathrm{N}_{2} \mathrm{O}$ emission from the two reactors was not distinguishable. Therefore, whether difference existed between the two reactors in terms of $\mathrm{N}_{2} \mathrm{O}$ emission couldn't be validated.

Based on the seasonal $\mathrm{N}_{2} \mathrm{O}$ emission pattern observed in this work (i.e., Fig. 2), control strategies are particularly needed in seasons with an increasing trend of water temperature (i.e., spring and summer) to mitigate $\mathrm{N}_{2} \mathrm{O}$ emission effectively, while their implementation in autumn and winter will further strengthen the abatement performance. As viable $\mathrm{N}_{2} \mathrm{O}$ control strategies need to deal with $\mathrm{N}_{2} \mathrm{O}$ emission dynamics under various process conditions, their 
development should be based on high-resolution analyses looking into the cyclic patterns associated with $\mathrm{N}_{2} \mathrm{O}$ emission in the reactors as well as the correlations between $\mathrm{N}_{2} \mathrm{O}$ emission and relevant process variables, which are presented in the following sections.

\subsection{Recurring Cyclic Patterns in High $\mathrm{N}_{2} \mathrm{O}$ Emission Seasons}

Fig. 3 delineates three types of recurring cyclic patterns in high $\mathrm{N}_{2} \mathrm{O}$ emission seasons, i.e., the sub-period with relatively high $\mathrm{N}_{2} \mathrm{O}$ emission identified in the previous section. In this work, a cycle was defined to consist of a preceding aerobic (aerated) phase and a following anoxic (non-aerated) phase, regulated by the STAR Control ${ }^{\circledR}$.

Cycles 1 to 4 in Fig. 3A represent the first type of recurring cyclic patterns. Upon the start of aeration in the aerobic phase, $\mathrm{NH}_{4}{ }^{+}$firstly increased without significant formation of $\mathrm{NO}_{3}{ }^{-}$. This was due to the higher supply of $\mathrm{NH}_{4}{ }^{+}$compared to its consumption through nitrification under limited DO conditions. $\mathrm{NO}_{2}^{-}$, which was not specifically monitored at the studied WWTP, might to some extent accumulate. Therefore, the absence of $\mathrm{N}_{2} \mathrm{O}$ production therein might indicate the insignificant role of the nitrifier denitrification pathway, which is typically triggered under low DO and/or high $\mathrm{NO}_{2}^{-}$conditions ${ }^{20-24}$. However, the potential contribution of the coexisting $\mathrm{HB}$ as the sole $\mathrm{N}_{2} \mathrm{O}$ scavenger in the reactors to $\mathrm{N}_{2} \mathrm{O}$ consumption could not be ruled out. Once DO reached a sufficiently high level, nitrification was enhanced. As a result, $\mathrm{NH}_{4}{ }^{+}$started to decrease, accompanied by the formation of $\mathrm{NO}_{3}{ }^{-}$. The co-occurring $\mathrm{N}_{2} \mathrm{O}$ production under ample DO conditions might originate from the hydroxylamine pathway 9,22 , 25. However, contrary to the reported simultaneous changes of nitrogenous compounds ${ }^{22,25}$, there existed an apparent lag phase between the emergence of $\mathrm{N}_{2} \mathrm{O}$ and the conversions of $\mathrm{NH}_{4}^{+}$ and $\mathrm{NO}_{3}^{-}$. This lag phase might be caused by the remaining heterotrophic $\mathrm{N}_{2} \mathrm{O}$ consumption under ample DO conditions, which was weakened with the formation of $\mathrm{NO}_{3}{ }^{-}$due to the 
competition between different denitrification steps for electron donors ${ }^{26,27}$. At the end of the aerobic phase, $\mathrm{NH}_{4}{ }^{+}$arrived at the bottom level while $\mathrm{NO}_{3}{ }^{-}$reached its peak. Once entering the anoxic phase, $\mathrm{NO}_{3}{ }^{-}$decreased immediately due to denitrification, while $\mathrm{NH}_{4}{ }^{+}$increased as a result of the consistent supply on top of the suspended nitrification process. Nevertheless, a different, non-monotonic behavior has been noticed for $\mathrm{N}_{2} \mathrm{O}$ production/emission. $\mathrm{N}_{2} \mathrm{O}$ firstly continued to increase for around 15 minutes, which clearly indicated the heterotrophic contribution to $\mathrm{N}_{2} \mathrm{O}$ production. When $\mathrm{NO}_{3}{ }^{-}$decreased to a low level at the end of the anoxic phase, $\mathrm{N}_{2} \mathrm{O}$ started to be consumed and was depleted quickly. In the anoxic phase when the whole compartment was not aerated, DO, an obligate electron acceptor for nitrification, became and remained at 0 . The suspension of the nitrification activity in the anoxic phase due to the unavailability of DO was further supported by the observation that nitrate didn't reappear after depletion while ammonium increased consistently due to the influent supply (see the higherresolution example Fig. S3 in the Supplementary Materials). Therefore, the observed trend between $\mathrm{N}_{2} \mathrm{O}$ and $\mathrm{NO}_{3}{ }^{-}$was likely the result of the higher preference of $\mathrm{HB}$ for reducing $\mathrm{NO}_{3}{ }^{-}$ than $\mathrm{N}_{2} \mathrm{O}$ in the competition for limited electron donors ${ }^{27,} 28$ or/and the presence of slowly biodegradable organics as electron donors which has been found to induce elevated $\mathrm{N}_{2} \mathrm{O}$ emission during denitrification ${ }^{10,29}$.

Fig. 3B shows the second type of recurring cyclic patterns. Compared to cycles 1 to 4 in Fig. $3 \mathrm{~A}$, the lowered $\mathrm{NH}_{4}{ }^{+}$loadings in cycles 5 to 7 led to the lowered $\mathrm{N}_{2} \mathrm{O}$ production probably through the hydroxylamine pathway during nitrification based on recent literature findings. However, no $\mathrm{N}_{2} \mathrm{O}$ was actually detected in the aerobic phase. This phenomenon could only be caused by the heterotrophic $\mathrm{N}_{2} \mathrm{O}$ consumption as $\mathrm{HB}$ were the sole $\mathrm{N}_{2} \mathrm{O}$ scavenger in the reactors. Consequently, $\mathrm{N}_{2} \mathrm{O}$ production/emission only occurred in the anoxic phase. Despite the difference in magnitude, $\mathrm{NO}_{3}{ }^{-}$and $\mathrm{N}_{2} \mathrm{O}$ had a correlation similar to the one observed in the 
first type of recurring cyclic patterns (i.e., Fig. 3A), further confirming the dual role of HB in

$\mathrm{N}_{2} \mathrm{O}$ turnover in the anoxic phase.

The third type of recurring cyclic patterns which covered all the cycles with $\mathrm{N}_{2} \mathrm{O}$ emission peaks in high $\mathrm{N}_{2} \mathrm{O}$ emission seasons are exampled by cycles 8 to 16 in Fig. 3C. Cycle 8 was largely analogous to the first type of recurring cyclic patterns presented in Fig. $3 \mathrm{~A}$, where $\mathrm{N}_{2} \mathrm{O}$ was produced and emitted in both the aerobic and anoxic phases. The major difference lied in the disappearance of $\mathrm{N}_{2} \mathrm{O}$ consumption in the anoxic phase (i.e., incomplete denitrification), which might be explained by the relatively high $\mathrm{NO}_{3}{ }^{-}$level at the end of the anoxic phase, thus placing the heterotrophic $\mathrm{N}_{2} \mathrm{O}$ consumption in a disadvantageous position in the competition for electron donors. This incomplete denitrification actually resulted from the inadequate length of anoxic phase determined by the STAR Control ${ }^{\circledR}$. Once entering the following cycle (i.e., cycle 9), the $\mathrm{N}_{2} \mathrm{O}$ accumulated in the liquid phase got stripped immediately, thus generating high $\mathrm{N}_{2} \mathrm{O}$ emission. This phenomenon of significantly higher $\mathrm{N}_{2} \mathrm{O}$ emission from reactors with intermittent aeration or compartments switching between aerobic and anoxic phases has also been documented in other types of activated sludge systems ${ }^{5,30}$. Despite the high $\mathrm{N}_{2} \mathrm{O}$ emission in the aerobic phase, the $\mathrm{N}_{2} \mathrm{O}$ level remained relatively stable, which might be due to i) the continuous $\mathrm{N}_{2} \mathrm{O}$ production during nitrification and ii) the depressed heterotrophic $\mathrm{N}_{2} \mathrm{O}$ consumption in the presence of the relatively high $\mathrm{NO}_{3}{ }^{-}$level. On account of the sole heterotrophic $\mathrm{N}_{2} \mathrm{O}$ production contribution, the accumulation of $\mathrm{N}_{2} \mathrm{O}$ continued until the end of the anoxic phase. The accumulated $\mathrm{N}_{2} \mathrm{O}$ got carried over to the next cycle (i.e., cycle 10), thus causing significantly high $\mathrm{N}_{2} \mathrm{O}$ emission in the aerobic phase. This cyclic pattern persisted for several cycles until cycle 14 , where the heterotrophic $\mathrm{N}_{2} \mathrm{O}$ consumption was observed in the anoxic phase (i.e., complete denitrification) due to the reduced $\mathrm{NO}_{3}^{-}$level 
before entering the next cycle, which resembled the first type of recurring cyclic patterns (i.e., Fig. 3A) and therefore only incurred relatively low $\mathrm{N}_{2} \mathrm{O}$ emission (see cycles 15 and 16 in Fig. $3 \mathrm{C})$.

\subsection{Correlations between $\mathrm{N}_{2} \mathrm{O}$ Emission and Process Variables}

Different from the reported Pearson's correlation analysis by Daelman et al. ${ }^{8}$ and Spearman's rank correlation analysis by Vasilaki et al. ${ }^{11}$, this work applied Pearson's partial correlation analysis to explore the degree of association between $\mathrm{N}_{2} \mathrm{O}$ emission and each process variable, with the effects of other process variables removed. In this work, following common practice, a PCC between 0 and 0.3 ( 0 and -0.3 ) was defined to indicate a weak positive (negative) correlation, a PCC between 0.3 and 0.7 (-0.3 and -0.7$)$ indicated a moderate positive (negative) correlation, and a PCC between 0.7 and 1.0 (-0.7 and -1.0) indicated a strong positive (negative) correlation. The two sub-periods identified in Fig. 2A were analyzed separately to probe into the change in the dependency of $\mathrm{N}_{2} \mathrm{O}$ emission on relevant process variables. Considering their significant difference in operational conditions and control scheme, the aerobic and anoxic phases, each accounting for around $85 \%$ and $15 \%$ of $\mathrm{N}_{2} \mathrm{O}$ emission on both monthly and yearly scale, were also analyzed separately in the partial correlation analysis. Even though a few fullscale studies reviewed by Vasilaki et al. ${ }^{12}$ exhibited negligible $\mathrm{N}_{2} \mathrm{O}$ emission in the anoxic phase without aeration, the significant relative contribution of the anoxic phase to $\mathrm{N}_{2} \mathrm{O}$ emission (i.e., 15\%) due to liquid-gas transfer was observed in this work. This might be caused by the differences between Avedøre WWTP and those WWTPs reviewed by Vasilaki et al. ${ }^{12}$ in the affecting pathways as well as the specific operational conditions.

Fig. 4A illustrates the PCC between $\mathrm{N}_{2} \mathrm{O}$ emission rate and process variables (including influent flowrate, $\mathrm{DO}, \mathrm{NH}_{4}{ }^{+}, \mathrm{NO}_{3}{ }^{-}$, and water temperature) in the aerobic phase of the sub- 
period with relatively high $\mathrm{N}_{2} \mathrm{O}$ emission. Among all the process variables studied in this work, only $\mathrm{NO}_{3}{ }^{-}$had a moderate positive correlation $(\mathrm{PCC}=0.33, \mathrm{p}=0.00)$ with $\mathrm{N}_{2} \mathrm{O}$ emission rate, which might indicate the main contribution of the hydroxylamine pathway during nitrification to the $\mathrm{N}_{2} \mathrm{O}$ production/emission. This was also supported by the weak positive correlations of $\mathrm{N}_{2} \mathrm{O}$ emission rate with $\mathrm{DO}(\mathrm{PCC}=0.20, \mathrm{p}=0.00)$ and $\mathrm{NH}_{4}{ }^{+}(\mathrm{PCC}=0.11, \mathrm{p}=0.00)$, which have been shown to possess a positive impact on the hydroxylamine pathway $9,22,25$. Water temperature also had a weak positive correlation $(\mathrm{PCC}=0.13, \mathrm{p}=0.00)$ with $\mathrm{N}_{2} \mathrm{O}$ emission rate, which might be due to the positive relationship between overall kinetics of nitrogen conversion processes and water temperature in the studied range (i.e., between $10^{\circ} \mathrm{C}$ and $20^{\circ} \mathrm{C}$ ) and was consistent with Ahn et al. ${ }^{6}$. Influent flowrate was found to insignificantly correlate with $\mathrm{N}_{2} \mathrm{O}$ emission rate $(\mathrm{PCC}=0.08, \mathrm{p}=0.14)$. As full nitrification was pursued at the studied WWTP through implementing high DO set-point (i.e., lowest DO set-point of $0.5 \mathrm{~g} \mathrm{~m}^{-3}$ when $\mathrm{NH}_{4}{ }^{+}$is $0 \mathrm{~g}-\mathrm{N} \mathrm{m}^{-3}$ ) and existing criteria of aerobic phase based on the in-situ $\mathrm{NH}_{4}{ }^{+} / \mathrm{NO}_{3}{ }^{-}$relationship in the STAR Control ${ }^{\circledR}, \mathrm{NO}_{2}{ }^{-}$might not have a significant impact on $\mathrm{N}_{2} \mathrm{O}$ emissions, although it has been found to highly correlate with $\mathrm{N}_{2} \mathrm{O}$ emission in other activated sludge systems ${ }^{8,11}$. This hypothesis couldn't be validated in this work due to the upfront technical limitation in onsite $\mathrm{NO}_{2}^{-}$measurement (i.e., unavailability), which is recommended as future work. Fig. 4B exhibits the PCC between $\mathrm{N}_{2} \mathrm{O}$ emission rate and process variables (including influent flowrate, $\mathrm{NH}_{4}{ }^{+}, \mathrm{NO}_{3}{ }^{-}$, and water temperature) in the anoxic phase of the sub-period with relatively high $\mathrm{N}_{2} \mathrm{O}$ emission. Compared to the weakly correlated influent flowrate, $\mathrm{NH}_{4}{ }^{+}$, and water temperature, $\mathrm{NO}_{3}{ }^{-}$had a moderate positive correlation $(\mathrm{PCC}=0.40, \mathrm{p}=0.00)$ with $\mathrm{N}_{2} \mathrm{O}$ emission rate, supporting the hypothesis that incomplete denitrification (caused by the competition between heterotrophic $\mathrm{NO}_{3}{ }^{-}$and $\mathrm{N}_{2} \mathrm{O}$ reduction for electron donors) contributed mainly to the $\mathrm{N}_{2} \mathrm{O}$ production/emission in the anoxic phase. 
Distinct results were obtained in the counterpart analysis of the aerobic (Fig. 4C) and anoxic

359

360

361

362

(Fig. 4D) phases of the sub-period with relatively low $\mathrm{N}_{2} \mathrm{O}$ emission. The first major difference lied in water temperature which appeared to have an around moderate negative correlation with $\mathrm{N}_{2} \mathrm{O}$ emission rate (i.e., PCC of -0.29 for the aerobic phase and -0.36 for the anoxic phase). The second major difference was associated with $\mathrm{NO}_{3}^{-}$which was found to be weakly correlated or uncorrelated with $\mathrm{N}_{2} \mathrm{O}$ emission rate. The distinct PCC results obtained for seasons with different magnitude of $\mathrm{N}_{2} \mathrm{O}$ emission manifested the change in key factors affecting $\mathrm{N}_{2} \mathrm{O}$ emission which led to the seasonality in $\mathrm{N}_{2} \mathrm{O}$ emission, as observed in Fig. 2. The fact that none of the studied process variables in Fig. 4 had a strong correlation with $\mathrm{N}_{2} \mathrm{O}$ emission rate was expected as strong correlations have been in fact rarely found in highly dynamic systems like WWTPs. This could be caused by some other process variables not accounted for in this work, which also gave rise to the significant discrepancy between Figs. 4A-B and Figs. 4C-D. For example, the microbial community structure might shift significantly in response to the declining trend in water temperature but remain relatively stable when facing the increasing water temperature, thus leading to the opposite PCC between water temperature and $\mathrm{N}_{2} \mathrm{O}$ emission rate as well as the different significance of $\mathrm{NO}_{3}{ }^{-}$in affecting $\mathrm{N}_{2} \mathrm{O}$ emission in Figs. 4A-B and Figs. 4C-D. Follow-up work in consideration of additional process variables such as microbial community dynamics is therefore highly desired in order to fully disclose the causes of the seasonal $\mathrm{N}_{2} \mathrm{O}$ emission.

\subsection{Implications for $\mathrm{N}_{2} \mathrm{O}$ Emission Quantification/Control, Testing of Control Concepts, and Future Work}

Using the off-line measured total Kjeldahl nitrogen (TKN) of composite samples to obtain the monthly average of nitrogen loading, the monthly $\mathrm{N}_{2} \mathrm{O}$ emission factor for Reactor 3 over the monitoring period was calculated to vary between $0.01 \%$ and $3.55 \%$, with a yearly level of 

0 to $14.6 \%$ organized by Daelman et al. ${ }^{8}$ but were largely (11 out of 12 monitored months, i.e., except September 2018) higher than the level of $0.035 \%$ proposed by IPCC ${ }^{3}$ (see Fig. 5). Therefore, guidelines provided by IPCC should be used with care in order to represent fullscale $\mathrm{N}_{2} \mathrm{O}$ emission. Considering the shortage of reliable modelling techniques capable of predicting long-term $\mathrm{N}_{2} \mathrm{O}$ emission as well as the rather complicated correlations between $\mathrm{N}_{2} \mathrm{O}$ emission and process variables, monitoring campaigns are still needed to report full-scale $\mathrm{N}_{2} \mathrm{O}$ emission. As discovered in Section 3.1, different $\mathrm{N}_{2} \mathrm{O}$ emission levels were observed for different reactors. Consequently, separate monitoring on different reactors should lead to more reliable quantification of the plant-wide $\mathrm{N}_{2} \mathrm{O}$ emission.

This work also provides useful insights for $\mathrm{N}_{2} \mathrm{O}$ emission control. As unveiled in Sections 3.2 and 3.3, HB had a dual role in the anoxic phase and could be responsible for both net $\mathrm{N}_{2} \mathrm{O}$ production and consumption, which tended to take place in sequence probably resulting from the competition between different denitrification steps for electron donors. Therefore, in order to avoid the accumulation of $\mathrm{N}_{2} \mathrm{O}$ as a result of incomplete denitrification which would be carried over to the following cycles and therefore subject to high emission, sufficient usage of the heterotrophic $\mathrm{N}_{2} \mathrm{O}$ consuming capability of the anoxic phase (i.e., complete denitrification) should be guaranteed through relevant control strategy such as extending the length of anoxic 402 phase. Practically, the peak $\mathrm{NH}_{4}{ }^{+}$level and the ending $\mathrm{NO}_{3}{ }^{-}$level in the aerobic phase of a certain cycle could be used as indicators of the need for relevant control strategy in the following anoxic phase. As shown in Fig. 6, when the peak $\mathrm{NH}_{4}{ }^{+}$level and the ending $\mathrm{NO}_{3}^{-}$ level in the aerobic phase nearly double compared to the conventional levels, it would be highly likely that $\mathrm{N}_{2} \mathrm{O}$ would accumulate at the end of the cycle and then get carrier over to the subsequent cycle, thus triggering high $\mathrm{N}_{2} \mathrm{O}$ emission. In this case, the aforementioned control 
strategy should be executed timely to prevent $\mathrm{N}_{2} \mathrm{O}$ emission peaks (i.e., significantly high $\mathrm{N}_{2} \mathrm{O}$ emission in the aerobic phase of cycles 9 to 14 in Fig. 3C). In fact, this finding regarding the important role of denitrification in mitigating $\mathrm{N}_{2} \mathrm{O}$ emission should be applicable to other activated sludge reactors with intermittent aeration or compartments switching between aerobic and anoxic phases. In Europe, according to relevant statistics, there are over 80 WWTPs that are using the STAR Control ${ }^{\circledR}$ as their control solution. For these plants, when needed, the current control system could be readily modified to reduce $\mathrm{N}_{2} \mathrm{O}$ emission through wisely controlling the anoxic phase.

Comparatively, control over the aerobic phase should be based more on the fact that the hydroxylamine pathway during nitrification was more likely to dominate the $\mathrm{N}_{2} \mathrm{O}$ production. Therefore, for the WWTP investigated in this work, reduced DO set-point might help reduce the $\mathrm{N}_{2} \mathrm{O}$ production through the hydroxylamine pathway. However, it remains unknown whether the reduced DO set-point would enhance the nitrifier denitrification pathway or not. To verify the efficacy of reduced DO set-point in mitigating $\mathrm{N}_{2} \mathrm{O}$ production/emission, a fullscale testing was conducted at Avedøre WWTP. To be brief, after a good baseline between Reactor 1 and Reactor 3 was obtained, the DO set-point in Reactor 3 was reduced by $0.5 \mathrm{~g} \mathrm{~m}^{-}$ ${ }^{3}$ (see Fig. S1A in the Supplementary Materials) to identify the disparities between Reactor 1 and Reactor 3 caused by the different DO set-points. To minimize potential threat to the stability of process operation, this full-scale testing only lasted for a week. As shown in Fig. 7, before the change in the DO set-point in Reactor 3 was made, the difference between Reactor 1 and Reactor 3 in terms of average $\mathrm{N}_{2} \mathrm{O}$ emission rate was less than 5\%. Moreover, as presented in Table 1, other process variables including MLSS and lengths of aerobic and anoxic phases were also quite comparable in both reactors. These similarities showed that both reactors should have comparable $\mathrm{N}_{2} \mathrm{O}$ emission during this period and therefore set the baseline 
needed for testing the proposed $\mathrm{N}_{2} \mathrm{O}$ control strategy. When the DO set-point in Reactor 3 was reduced by $0.5 \mathrm{~g} \mathrm{~m}^{-3}$, the average $\mathrm{N}_{2} \mathrm{O}$ emission rate in Reactor 3 was $60 \%$ lower than that in emission rate in Reactor 1 with the default DO set-point might be the result of the different influent flowrate/composition conditions and the increasing trend of water temperature. As manifested in Table 1, the reduced DO set-point extended the length of the aerobic phase in Reactor 3 by $13 \%$, compared to Reactor 1 . This phenomenon was expected as a longer duration would be needed when the nitrification intensity was weakened by the reduced DO set-point. Additionally, the reduced DO set-point also indirectly affected the anoxic phase. Compared to Reactor 1, the length of the anoxic phase in Reactor 3 was extended by $33 \%$. This observation was in line with the aforementioned control over the anoxic phase to reduce $\mathrm{N}_{2} \mathrm{O}$ emission. In short, the proposed concepts of control over the closely related aerobic and anoxic phases were evaluated collectively by this full-scale testing of reduced DO set-point. In addition to proving the efficacy of properly reduced DO set-point in mitigating $\mathrm{N}_{2} \mathrm{O}$ emission from WWTPs with similar plant/process configuration and control scheme to Avedøre WWTP, the results of this full-scale testing might also serve as practical evidence supporting the hypotheses on the $\mathrm{N}_{2} \mathrm{O}$ producing pathways proposed based on recent literature findings.

Although Foley et al. ${ }^{15}$ claimed that the concentrations of nitrogenous compounds could be assumed to approach perfectly mixed conditions in a Carrousel compartment, the real uniformity of each process variable is barely possible to achieve at full-scale WWTPs. Potential spatial heterogeneity could be checked by placing a second set of measuring sensors in the compartment. However, the fact that the existing sensors are installed around the same place ensures the comparability between process variables, laying the solid foundation for the analyses done in this work. Besides the one-year data presented in this work, the availability 
458 of more data is highly desired to clarify whether $\mathrm{N}_{2} \mathrm{O}$ emission would differ from year to year.

459 The hypotheses regarding the $\mathrm{N}_{2} \mathrm{O}$ production pathways were proposed based on recent

460 literature findings and could be proved/tested with the availability of on-line $\mathrm{NO}_{2}^{-}$,

461 hydroxylamine and COD measurements and biological measurements as well as the help of in-

462 situ isotope tracing techniques ${ }^{31}$ and sophisticated mathematical modelling, which are the 463 focus of future work.

464

465

\section{ACKNOWLEDGEMENTS}

466

467

468

469

470

471

472

473

474

475

476

477

478

479

480

481

482

This work was supported by VUDP (Vandsektorens Udviklings- og Demonstrationsprogram) through "Demonstration af en ny kontrol metode til at reducere lattergas udledningen fra renseanlæg" Project (ID No. 87.2016). Dr. Xueming Chen acknowledges the financial support by the European Union's Horizon 2020 research and innovation programme through Marie Skłodowska-Curie Individual Fellowship under grant agreement No. 790231.

\section{SUPPORTING INFORMATION}

Supplementary Data: On-line data for all process variables (including influent flowrate, DO, $\mathrm{NH}_{4}{ }^{+}, \mathrm{NO}_{3}{ }^{-}, \mathrm{N}_{2} \mathrm{O}$, and temperature) and calculated $\mathrm{N}_{2} \mathrm{O}$ emission rates over the 12-month monitoring period.

Supplementary Materials: Details about Pearson's partial correlation analysis; Settings of the default and tested STAR Control ${ }^{\circledR}$ (Fig. S1); Dynamic profiles of process variables in the two parallel reactors with similar concentrations and behavior of $\mathrm{NH}_{4}{ }^{+}, \mathrm{NO}_{3}{ }^{-}$, and $\mathrm{DO}$ but different ranges and responses of $\mathrm{N}_{2} \mathrm{O}$ (Fig. S2); Cyclic data showing lack of nitrification activity in the anoxic phase (Fig. S3). 


\section{REFERENCES}

484

485

486

487

488

489

490

491

492

493

494

495

496

497

498

499

500

501

502

503

504

505

1. Hanaki, K.; Hong, Z.; Matsuo, T. Production of Nitrous Oxide Gas during Denitrification of Wastewater. Water Science and Technology 1992, 26, (5-6), 1027-1036.

2. Czepiel, P.; Crill, P.; Harriss, R. Nitrous Oxide Emissions from Municipal Wastewater Treatment. Environmental Science \& Technology 1995, 29, (9), 2352-2356.

3. IPCC Climate Change 2014: Synthesis Report. Contribution of Working Groups I, II and III to the Fifth Assessment Report of the Intergovernmental Panel on Climate Change; IPCC, Geneva, Switzerland, 2014; p 151.

4. Ravishankara, A. R.; Daniel, J. S.; Portmann, R. W. Nitrous Oxide (N2O): The Dominant Ozone-Depleting Substance Emitted in the 21st Century. Science 2009, 326, (5949), 123125.

5. Aboobakar, A.; Cartmell, E.; Stephenson, T.; Jones, M.; Vale, P.; Dotro, G. Nitrous oxide emissions and dissolved oxygen profiling in a full-scale nitrifying activated sludge treatment plant. Water Research 2013, 47, (2), 524-534.

6. Ahn, J. H.; Kim, S.; Park, H.; Rahm, B.; Pagilla, K.; Chandran, K. N2O Emissions from Activated Sludge Processes, 2008-2009: Results of a National Monitoring Survey in the United States. Environmental Science \& Technology 2010, 44, (12), 4505-4511.

7. Yoshida, H.; Mønster, J.; Scheutz, C. Plant-integrated measurement of greenhouse gas emissions from a municipal wastewater treatment plant. Water Research 2014, 61, 108 118.

8. Daelman, M. R. J.; van Voorthuizen, E. M.; van Dongen, U. G. J. M.; Volcke, E. I. P.; van Loosdrecht, M. C. M. Seasonal and diurnal variability of N2O emissions from a full-scale municipal wastewater treatment plant. Science of The Total Environment 2015, 536, 1-11. 
506 9. Chandran, K.; Stein, L. Y.; Klotz, M. G.; van Loosdrecht, M. C. M. Nitrous oxide 507 production by lithotrophic ammonia-oxidizing bacteria and implications for engineered 508 nitrogen-removal systems. Biochem Soc T 2011, 39, 1832-1837.

10. Massara, T. M.; Malamis, S.; Guisasola, A.; Baeza, J. A.; Noutsopoulos, C.; Katsou, E. A review on nitrous oxide (N2O) emissions during biological nutrient removal from municipal wastewater and sludge reject water. Science of The Total Environment 2017, $596,106-123$.

11. Vasilaki, V.; Volcke, E. I. P.; Nandi, A. K.; van Loosdrecht, M. C. M.; Katsou, E. Relating $\mathrm{N} 2 \mathrm{O}$ emissions during biological nitrogen removal with operating conditions using multivariate statistical techniques. Water Research 2018, 140, 387-402.

12. Vasilaki, V.; Massara, T. M.; Stanchev, P.; Fatone, F.; Katsou, E. A decade of nitrous oxide (N2O) monitoring in full-scale wastewater treatment processes: A critical review. Water Research 2019, 161, 392-412.

13. Boiocchi, R.; Gernaey, K. V.; Sin, G. A novel fuzzy-logic control strategy minimizing N2O emissions. Water Research 2017, 123, 479-494.

14. Schulthess, R. V.; Gujer, W. Release of nitrous oxide (N2O) from denitrifying activated sludge: Verification and application of a mathematical model. Water Research 1996, 30, (3), 521-530.

15. Foley, J.; de Haas, D.; Yuan, Z.; Lant, P. Nitrous oxide generation in full-scale biological nutrient removal wastewater treatment plants. Water Research 2010, 44, (3), 831-844.

16. Marques, R.; Rodriguez-Caballero, A.; Oehmen, A.; Pijuan, M. Assessment of online monitoring strategies for measuring $\mathrm{N} 2 \mathrm{O}$ emissions from full-scale wastewater treatment systems. Water Research 2016, 99, 171-179.

17. Nuzzo, R. Scientific method: statistical errors. Nature News 2014, 506, (7487), 150. 
18. Sin, G.; Gernaey, K. V.; Neumann, M. B.; van Loosdrecht, M. C. M.; Gujer, W. Global sensitivity analysis in wastewater treatment plant model applications: Prioritizing sources of uncertainty. Water Research 2011, 45, (2), 639-651.

19. Kosonen, H.; Heinonen, M.; Mikola, A.; Haimi, H.; Mulas, M.; Corona, F.; Vahala, R. Nitrous Oxide Production at a Fully Covered Wastewater Treatment Plant: Results of a Long-Term Online Monitoring Campaign. Environmental Science \& Technology 2016, 50, (11), 5547-5554.

20. Peng, L.; Ni, B.-J.; Ye, L.; Yuan, Z. The combined effect of dissolved oxygen and nitrite on $\mathrm{N} 2 \mathrm{O}$ production by ammonia oxidizing bacteria in an enriched nitrifying sludge. Water Research 2015, 73, (0), 29-36.

21. Kampschreur, M. J.; Tan, N. C. G.; Kleerebezem, R.; Picioreanu, C.; Jetten, M. S. M.; Loosdrecht, M. C. M. Effect of dynamic process conditions on nitrogen oxides emission from a nitrifying culture. Environmental Science \& Technology 2008, 42, (2), 429-435.

22. Peng, L.; Ni, B.-J.; Erler, D.; Ye, L.; Yuan, Z. The effect of dissolved oxygen on N2O production by ammonia-oxidizing bacteria in an enriched nitrifying sludge. Water Research 2014, 66, 12-21.

23. Wunderlin, P.; Mohn, J.; Joss, A.; Emmenegger, L.; Siegrist, H. Mechanisms of N2O production in biological wastewater treatment under nitrifying and denitrifying conditions. Water Research 2012, 46, (4), 1027-1037.

24. Rassamee, V.; Sattayatewa, C.; Pagilla, K.; Chandran, K. Effect of Oxic and Anoxic Conditions on Nitrous Oxide Emissions from Nitrification and Denitrification Processes. Biotechnol Bioeng 2011, 108, (9), 2036-2045.

25. Chen, X.; Yuan, Z.; Ni, B.-J. Nitrite accumulation inside sludge flocs significantly influencing nitrous oxide production by ammonium-oxidizing bacteria. Water Research 2018, 143, 99-108. 
555

556

557

558

559

560

561

562

563

564

565

566

567

568

569

570

571

26. Chen, X.; Ni, B.-J.; Sin, G. Nitrous Oxide Production in Autotrophic Nitrogen Removal Granular Sludge: A Modeling Study. Biotechnol Bioeng 2019, 116, (6), 1280-1291.

27. Pan, Y. T.; Ni, B. J.; Bond, P. L.; Ye, L.; Yuan, Z. G. Electron competition among nitrogen oxides reduction during methanol-utilizing denitrification in wastewater treatment. Water Research 2013, 47, (10), 3273-3281.

28. Ni, B. J.; Yuan, Z. G. Recent advances in mathematical modeling of nitrous oxides emissions from wastewater treatment processes. Water Research 2015, 87, 336-346.

29. Schalk-Otte, S.; Seviour, R. J.; Kuenen, J. G.; Jetten, M. S. M. Nitrous oxide (N2O) production by Alcaligenes faecalis during feast and famine regimes. Water Research 2000 , $34,(7), 2080-2088$.

30. Yang, Q.; Liu, X.; Peng, C.; Wang, S.; Sun, H.; Peng, Y. N2O Production during Nitrogen Removal via Nitrite from Domestic Wastewater: Main Sources and Control Method. Environmental Science \& Technology 2009, 43, (24), 9400-9406.

31. Wunderlin, P.; Lehmann, M. F.; Siegrist, H.; Tuzson, B.; Joss, A.; Emmenegger, L.; Mohn, J. Isotope Signatures of N2O in a Mixed Microbial Population System: Constraints on N2O Producing Pathways in Wastewater Treatment. Environmental Science \& Technology 2013, 47, (3), 1339-1348. 
Table and Figure Legends

574

575

Table 1. Results of full-scale testing of reduced DO set-point.

Figure 1. Schematic diagram of Carrousel reactor comprising two alternatively fed and intermittently aerated compartments (Locations of measuring sensors with respect to water flow direction are marked).

Figure 2. Seasonal $\mathrm{N}_{2} \mathrm{O}$ emission pattern in (A) Reactor 3 and (B) Reactor 1 (Highlighted box in (B) indicates months when $\mathrm{N}_{2} \mathrm{O}$ was only monitored in one compartment or both $\mathrm{N}_{2} \mathrm{O}$ sensors were not in service).

Figure 3. Three types of recurring cyclic patterns in seasons with relatively high $\mathrm{N}_{2} \mathrm{O}$ emission.

Figure 4. Pearson's partial correlation coefficients between monitored process variables and $\mathrm{N}_{2} \mathrm{O}$ emission rate in (A and $\left.\mathbf{C}\right)$ aerobic and (B and $\left.\mathbf{D}\right)$ anoxic phase of seasons with relatively (A and B) high and (C and D) low $\mathrm{N}_{2} \mathrm{O}$ emission (Highlighted box indicates partial correlation coefficient not significantly different from zero, i.e., $\mathrm{p}>0.05)$.

Figure 5. $\mathrm{N}_{2} \mathrm{O}$ emission factors of Reactor 3 over monitoring period and comparison with IPCC proposed level.

Figure 6. Comparison of peak $\mathrm{NH}_{4}{ }^{+}$level in aerobic phase and $\mathrm{NO}_{3}{ }^{-}$level at the end of aerobic phase between cycles without and with $\mathrm{N}_{2} \mathrm{O}$ carrying over to subsequent cycle in peak $\mathrm{N}_{2} \mathrm{O}$ emission month.

Figure 7. Comparison of $\mathrm{N}_{2} \mathrm{O}$ emission rate between (A) Reactor 1 and (B) Reactor 3 (Green region in $\mathbf{B}$ indicates period when DO set-point in Reactor 3 was reduced by $0.5 \mathrm{~g}$ $\left.m^{-3}\right)$ 
Table 1. Results of full-scale testing of reduced DO set-point.

\begin{tabular}{|c|c|c|c|c|c|c|c|c|}
\hline & \multicolumn{2}{|c|}{$\begin{array}{l}\text { Average MLSS } \\
\quad\left(\mathrm{kg} \mathrm{m}^{-3}\right)\end{array}$} & \multicolumn{2}{|c|}{$\begin{array}{c}\text { Average length of aerobic phase } \\
\text { (min) }\end{array}$} & \multicolumn{2}{|c|}{$\begin{array}{c}\text { Average length of anoxic phase } \\
\text { (min) }\end{array}$} & \multicolumn{2}{|c|}{$\begin{array}{l}\text { Average } \mathrm{N}_{2} \mathrm{O} \text { emission rate } \\
\qquad\left(\mathrm{g} \mathrm{N} \mathrm{m}^{-3} \mathrm{~d}^{-1}\right)\end{array}$} \\
\hline & Reactor 1 & Reactor 3 & Reactor 1 & Reactor 3 & Reactor 1 & Reactor 3 & Reactor 1 & Reactor 3 \\
\hline $\begin{array}{l}\text { Baseline: } \\
\text { Default DO set-point }\end{array}$ & 2.21 & 2.22 & 54.2 & 54.1 & 34.1 & 37.4 & $4.1 \pm 0.1$ & $3.9 \pm 0.1$ \\
\hline $\begin{array}{l}\text { Testing: } \\
\text { Reduced DO set-point in Reactor } 3\end{array}$ & 2.18 & 2.28 & 98.2 & 111.1 & 31.3 & 41.7 & $10.1 \pm 0.2$ & $4.0 \pm 0.1$ \\
\hline
\end{tabular}


598 Figure 1. Schematic diagram of Carrousel reactor comprising two alternatively fed and

599 intermittently aerated compartments (Locations of measuring sensors with respect to water 600 flow direction are marked). 


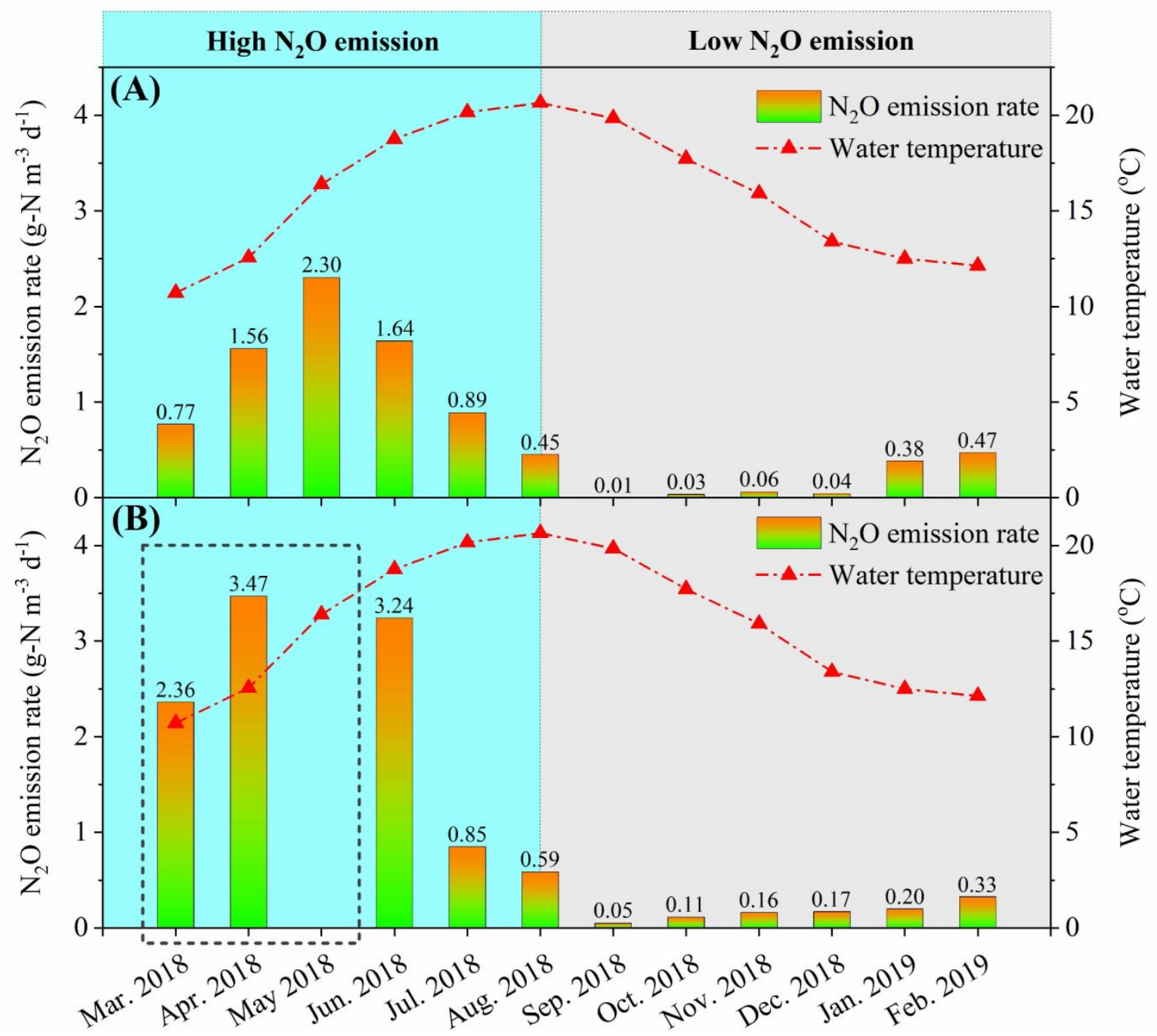

602 Figure 2. Seasonal $\mathrm{N}_{2} \mathrm{O}$ emission pattern in (A) Reactor 3 and (B) Reactor 1 (Highlighted box 603 in (B) indicates months when $\mathrm{N}_{2} \mathrm{O}$ was only monitored in one compartment or both $\mathrm{N}_{2} \mathrm{O}$ 604 sensors were not in service). 

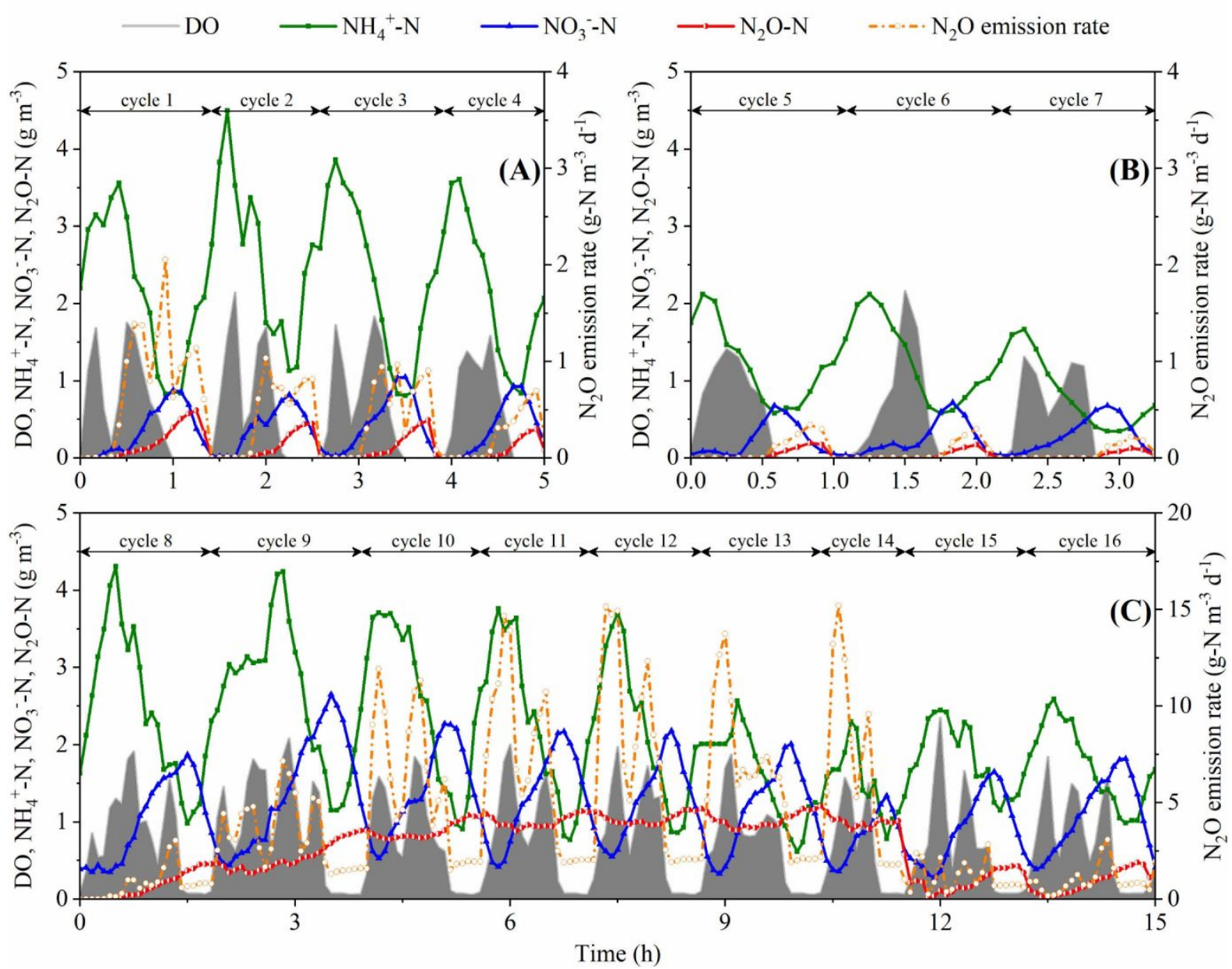

605

Time (h)

606 Figure 3. Three types of recurring cyclic patterns in seasons with relatively high $\mathrm{N}_{2} \mathrm{O}$ emission. 

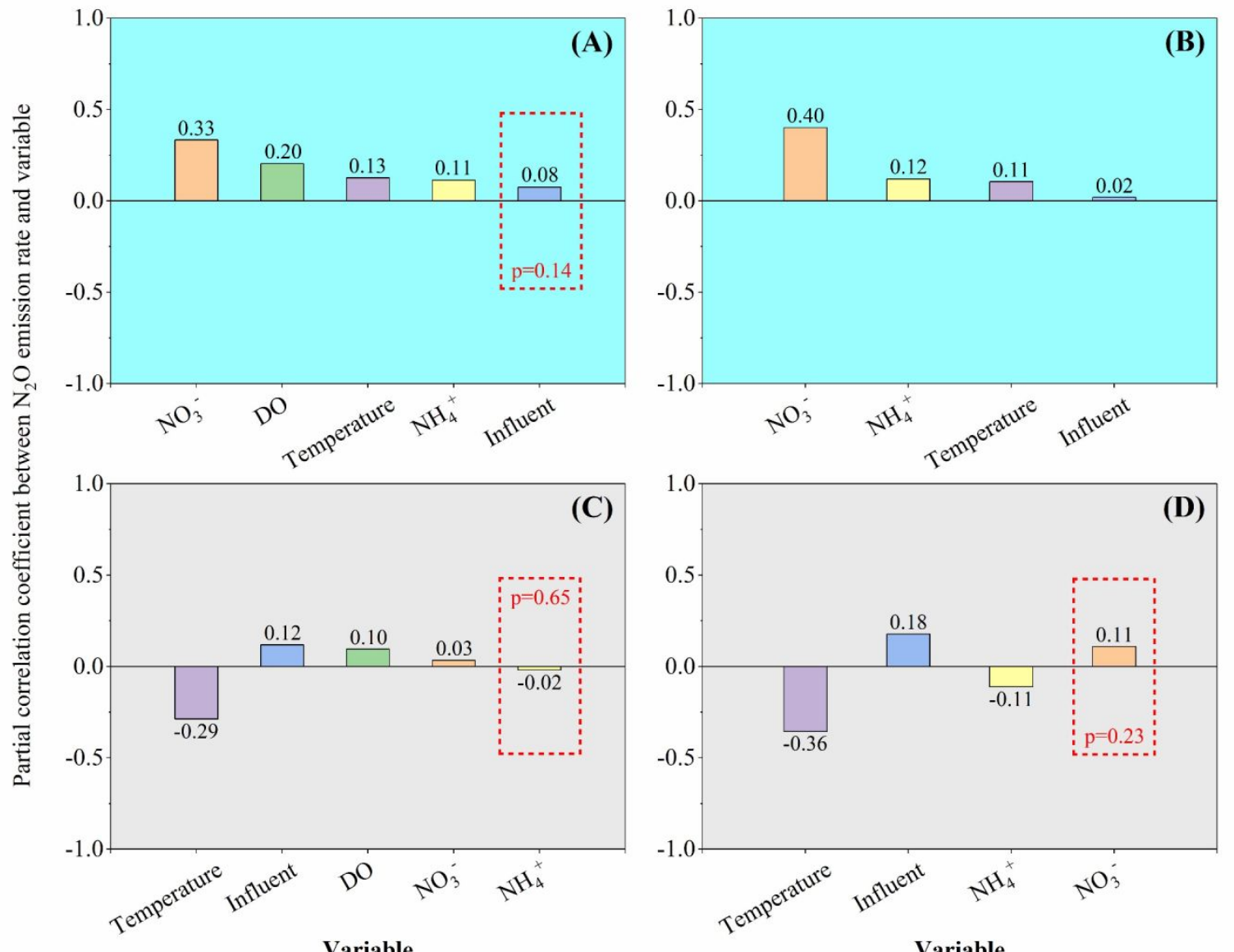

608 Figure 4. Pearson's partial correlation coefficients between monitored process variables and $609 \mathrm{~N}_{2} \mathrm{O}$ emission rate in (A and $\left.\mathbf{C}\right)$ aerobic and (B and $\left.\mathbf{D}\right)$ anoxic phase of seasons with relatively 610 (A and $\mathbf{B})$ high and (C and $\mathbf{D})$ low $\mathrm{N}_{2} \mathrm{O}$ emission (Highlighted box indicates partial correlation coefficient not significantly different from zero, i.e., $\mathrm{p}>0.05$ ). 


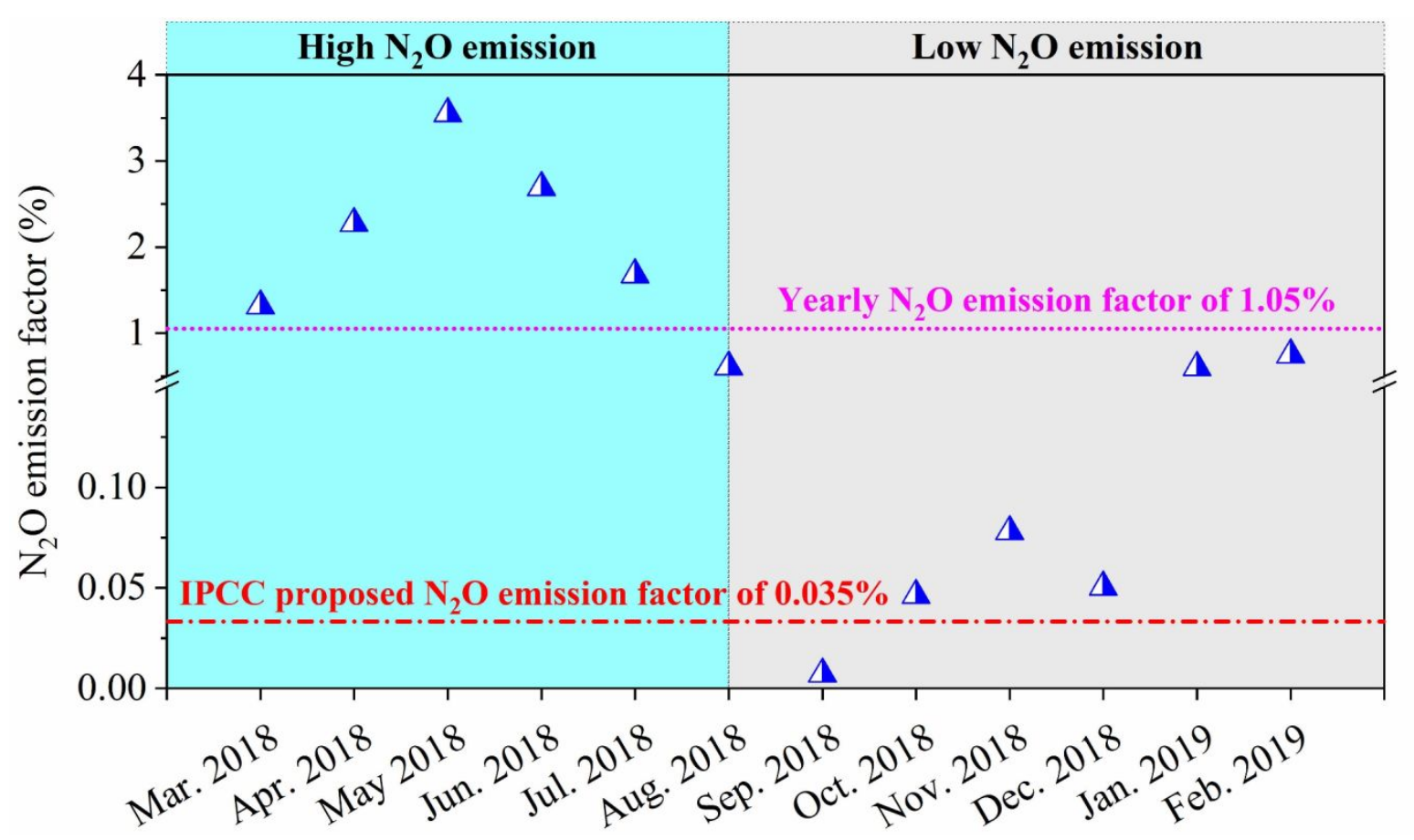

613 Figure 5. $\mathrm{N}_{2} \mathrm{O}$ emission factors of Reactor 3 over monitoring period and comparison with IPCC 614 proposed level. 
615

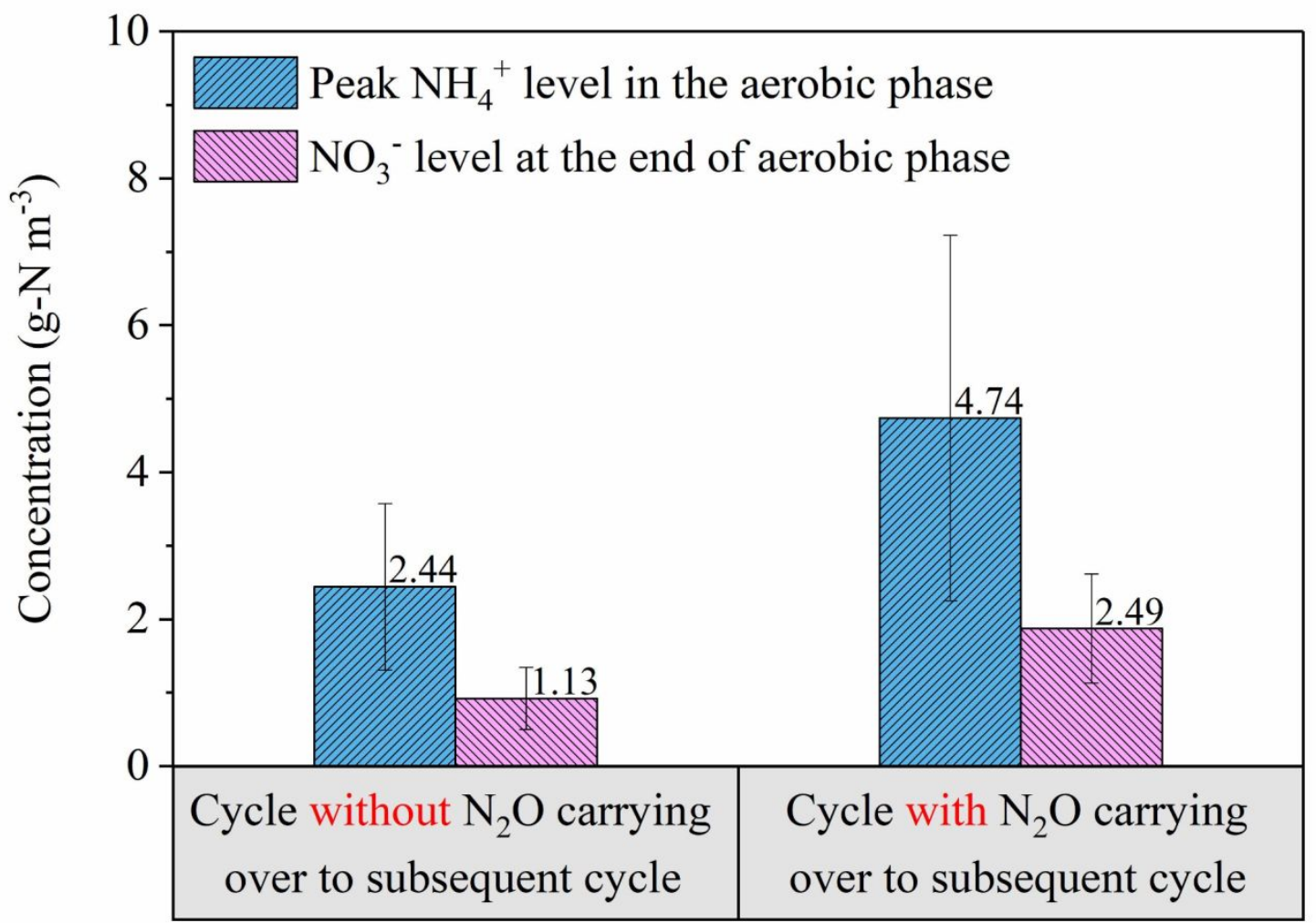

616 Figure 6. Comparison of peak $\mathrm{NH}_{4}{ }^{+}$level in aerobic phase and $\mathrm{NO}_{3}{ }^{-}$level at the end of aerobic

617 phase between cycles without and with $\mathrm{N}_{2} \mathrm{O}$ carrying over to subsequent cycle in peak $\mathrm{N}_{2} \mathrm{O}$ 618 emission month. 

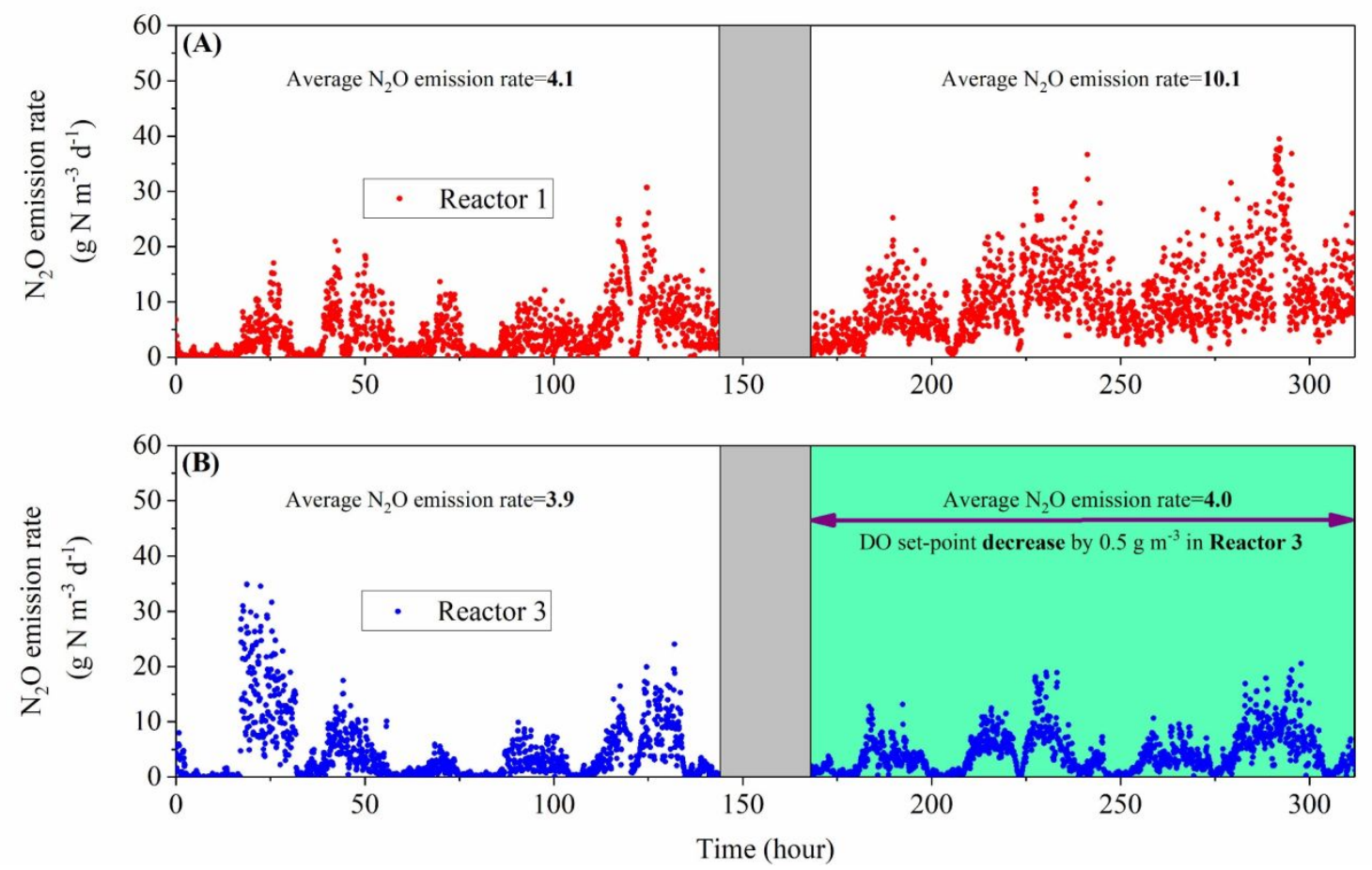

619

620 Figure 7. Comparison of $\mathrm{N}_{2} \mathrm{O}$ emission rate between (A) Reactor 1 and (B) Reactor 3 (Green

621 region in $\mathbf{B}$ indicates period when DO set-point in Reactor 3 was reduced by $0.5 \mathrm{~g} \mathrm{~m}^{-3}$ ). 